\title{
Influence of environmental changes on picophytoplankton and bacteria in Daya Bay, South China Sea
}

\section{Influencia de cambios ambientales en picofitoplancton y bacterias en la bahía de Daya, mar de China Meridional}

\author{
Mei-Lin Wu ${ }^{1 *}$, Yu-Tu Wang ${ }^{1,2}$, You-Shao Wang ${ }^{1,2}$, Fu-Lin Sun ${ }^{1,2}$ \\ ${ }^{1}$ State Key Laboratory of Tropical Oceanography, South China Sea Institute of Oceanology, Chinese Academy \\ of Sciences, Guangzhou 510301, China. \\ ${ }^{2}$ Marine Biology Research Station at Daya Bay, Chinese Academy of Sciences, Shenzhen 518121, China. \\ * Corresponding author. E-mail: mlwu@scsio.ac.cn
}

\begin{abstract}
Environmental changes driven by intense human disturbance and natural processes govern the abundance and distribution characteristics of two picophytoplankton groups (Synechococcus and picoeukaryotes). Picophytoplancton and high DNA (HDNA) and low DNA (LDNA) bacterial groups, identified by flow cytometry, were assessed during the autumn monsoon transition period in Daya Bay (South China Sea). The abundance of Synechococcus and picoeukaryotes ranged from $2.16 \times 10^{4}$ to $1.45 \times 10^{5}$ cell $\mathrm{mL}^{-1}$ and from $0.78 \times 10^{3}$ to $7.95 \times 10^{3}$ cell $\mathrm{mL}^{-1}$, respectively. The abundance of HDNA bacteria in surface water (mean: $5.58 \times 10^{5} \mathrm{cell}^{\mathrm{mL}} \mathrm{m}^{-1}$ ) was greater than in bottom water (mean: $3.74 \times 10^{5}$ cell $\mathrm{mL}^{-1}$ ), with significant difference $(n=12, P=0.05)$. The difference in LDNA abundances between surface (mean: $7.06 \times 10^{5}$ cell $\left.\mathrm{mL}^{-1}\right)$ and bottom (mean: $4.83 \times 10^{5}$ cell $\left.\mathrm{mL}^{-1}\right)$ waters was insignificant $(n=12, P>0.05)$. The results of the principal component analysis showed that both picophytoplankton (Synechococcus and picoeukaryotes) and bacteria (HDNA and LDNA) were positively related to nutrients $\left(\mathrm{NO}_{3}-\mathrm{N}, \mathrm{NH}_{4}-\mathrm{N}\right.$, and $\left.\mathrm{SiO}_{3}-\mathrm{Si}\right)$. Three subsystems in the bay were identified as follows: the west and east parts, the central and northwest parts, and the mouth and central part.
\end{abstract}

Key words: picophytoplankton, bacteria, flow cytometry, Daya Bay.

RESUMEN. Los cambios ambientales generados por las actividades humanas y los procesos naturales determinan las características de la distribución y abundancia de dos grupos de picofitoplancton (Synechococcus y picoeucariontes). Se evaluaron las comunidades de picofitoplancton y de bacterias con mayor (MaADN) y menor (MeADN) cantidad de ADN, identificadas mediante citometría de flujo, durante el periodo de transición intermonzónico en otoño en la bahía de Daya (mar de China Meridional). La abundancia de Synechococcus y

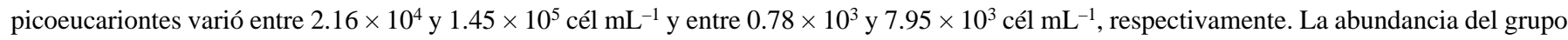

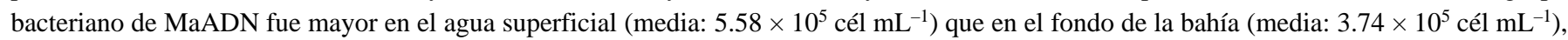
con una diferencia significativa $(n=12, P=0.05)$. No se observó una diferencia significativa entre la abundancia del grupo de MeADN en la superficie (media: $7.06 \times 10^{5}$ cél $\left.\mathrm{mL}^{-1}\right)$ y el fondo (media: $4.83 \times 10^{5}$ cél mL $\left.\mathrm{m}^{-1}\right)(n=12, P>0.05)$. Un análisis de componentes principales mostró que ambos grupos de picofitoplancton (Synechococcus y picoeucariontes) y bacterias (MaADN y MeADN) se relacionaron positivamente con nutrientes $\left(\mathrm{NO}_{3}-\mathrm{N}, \mathrm{NH}_{4}-\mathrm{N}\right.$ y SiO $\left.3-\mathrm{Si}\right)$. Se identificaron tres subsistemas en la bahía: las partes oeste y este, las partes central y noroeste, y la boca y parte central.

Palabras clave: picofitoplancton, bacterias, citometría de flujo, bahía de Daya.

\section{INTRODUCTION}

Coastal bays are very complex and fragile ecosystems affected by human activities and natural processes such as monsoons (Jickells 1998). Half of the world's population now lives within $60 \mathrm{~km}$ of the coast. Coastal pollution often results in adverse conditions leading to the development of harmful algal blooms and/or eutrophication. This has resulted in an ecological unbalance, the loss of biodiversity, and the rapid reduction of biological resources ( $\mathrm{Wu}$ et al. 2012). Moreover, there is a large input of pollutants to the coastal

\section{INTRODUCCIÓN}

Las bahías costeras son ecosistemas muy complejos y frágiles, afectados por actividades humanas y fenómenos naturales como los monzones (Jickells 1998). La mitad de la población mundial actualmente vive dentro de los primeros $60 \mathrm{~km}$ de la costa. La contaminación costera frecuentemente genera condiciones adversas que provocan el desarrollo de afloramientos algales nocivos y/o la eutrofización. Esto ha causado un desequilibrio ecológico, una pérdida de biodiversidad y una disminución de los recursos biológicos (Wu et al. 
seas as a result of the land and ocean interaction in the coastal zone.

Daya Bay (South China Sea) is a special ecosystem under strong pressure or impact from natural phenomena (Southeast Asian monsoons) and anthropogenic activities (e.g., aquaculture, nuclear power plants) (Xu 1989, Wang et al. 2006, Wu and Wang 2007, Wang et al. 2008, Wang et al. 2009). Pollutants entering a bay system normally result from many transport pathways including wastewater, runoff effluents, land reclamation, recreation, and fish culture, as well as atmospheric deposition and climate change. This complex coastal system is the reason for the implementation of environmental monitoring programs intended to produce a better understanding and management of the ecosystems within it (Wu and Wang 2007; Wang et al. 2008; Wu et al. 2009, 2010).

Whether this ecosystem influenced by human activities and natural processes has a different spatial structure and how this has affected the picophytoplankton community and bacteria in the area is still unclear. This study was designed to investigate the physical and chemical properties and phytoplankton and bacterial abundances in this coastal ecosystem to identify whether the dynamics of the phytoplankton community and bacteria is associated with the autumn monsoon transition period.

\section{MATERIALS AND METHODS}

\section{Study area}

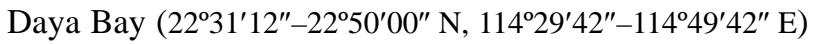
is located on the southern coast of China (fig. 1). The bay water is administrated by the Shenzhen and Huizhou municipal governments. Shenzhen manages the southwest coast area of Daya Bay (Dapeng town and Nan Ao). Huizhou manages the north and east coast area (Aotou, Danshui, Xiachong, Nianshan, and Xunliao). In the past 30 years, the rapid economic development and anthropogenic activities of Shenzhen and Huizhou have greatly influenced the environment of this bay. For example, two nuclear power stations, Daya Bay Nuclear Power Plant and Lingao Nuclear Power Plant, have been operated since 1993 and 2003, respectively. In addition, the marine aquaculture industry has been one of the most important industries of the bay. The weaker southwest monsoon prevails from May to September and the stronger northeast monsoon from October to April.

\section{Sampling and analysis}

Seawater samples were taken from the surface $(0.5 \mathrm{~m}$ below the surface) and bottom ( $2 \mathrm{~m}$ above the bottom) at 12 stations (S1-S12) in January (winter), April (spring), August (summer), and November (autumn) 2012. Temperature, $\mathrm{pH}$, and salinity at the surface and bottom depths were determined by a Quanta Water Quality Monitoring System
2012). Además, las aguas costeras reciben una gran cantidad de contaminantes como consecuencia de la interacción entre la tierra y el océano en la zona costera.

La bahía de Daya (mar de China Meridional) es un ecosistema especial impactado fuertemente por fenómenos naturales (monzones del Sureste de Asia) y actividades antropogénicas (e.g., acuicultura, plantas de energía nuclear) (Xu 1989, Wang et al. 2006, Wu y Wang 2007, Wang et al. 2008, Wang et al. 2009). Los contaminantes introducidos en un sistema costero normalmente se asocian con las descargas de aguas residuales, los efluentes de escorrentía, la reclamación de tierras, el cultivo de peces, actividades recreacionales, la deposición atmosférica y el cambio climático. Se han realizado varios estudios ambientales en la bahía de Daya para tener un mejor entendimiento y contribuir a un mejor manejo de los ecosistemas dentro de ella (Wu y Wang 2007; Wang et al. 2008; Wu et al. 2009, 2010).

Aún no queda claro si este ecosistema impactado por actividades humanas y procesos naturales tiene una estructura espacial diferente y si esto afecta las comunidades de picofitoplancton y bacterias. El objetivo de este estudio fue analizar las propiedades físicas y químicas, y la abundancia de las comunidades fitoplanctónicas y bacterianas en este ecosistema costero para identificar si la dinámica de la comunidad de fitoplancton y las bacterias se relaciona con el periodo de transición intermonzónico en otoño.

\section{MATERIALES Y MÉTODOS}

\section{Área de estudio}

La bahía de Daya $\left(22^{\circ} 31^{\prime} 12^{\prime \prime}-22^{\circ} 50^{\prime} 00^{\prime \prime} \mathrm{N}\right.$, $114^{\circ} 29^{\prime} 42^{\prime \prime}-114^{\circ} 49^{\prime} 42^{\prime \prime}$ E) se localiza en la costa sur de China (fig. 1). El agua de la bahía es administrada por los gobiernos municipales de Shenzhen y Huizhou. Shenzhen administra la parte suroeste de la bahía (localidades de Dapeng y Nan Ao), mientras que Huizhou administra la parte norte y este (Aotou, Danshui, Xiachong, Nianshan y Xunliao). Durante los pasados 30 años, el rápido desarrollo económico y las actividades antropogénicas de Shenzhen y Huizhou han afectado fuertemente el ambiente. La planta de energía nuclear de la bahía de Daya inició operaciones en 1993 y la planta de energía nuclear de Lingao inició operaciones en 2003. La acuicultura marina es una de las industrias más importantes de la bahía. El monzón del suroeste (más débil) prevalece de mayo a septiembre y el monzón del noreste (más fuerte) de octubre a abril.

\section{Muestreo y análisis}

Se recolectaron muestras de agua de mar de la superficie ( $0.5 \mathrm{~m}$ por debajo de la superficie) y el fondo ( $2 \mathrm{~m}$ por encima del fondo) en 12 estaciones (S1-S12) en enero (invierno), abril (primavera), agosto (verano) y noviembre (otoño) de 2012. Se realizaron mediciones de temperatura, 


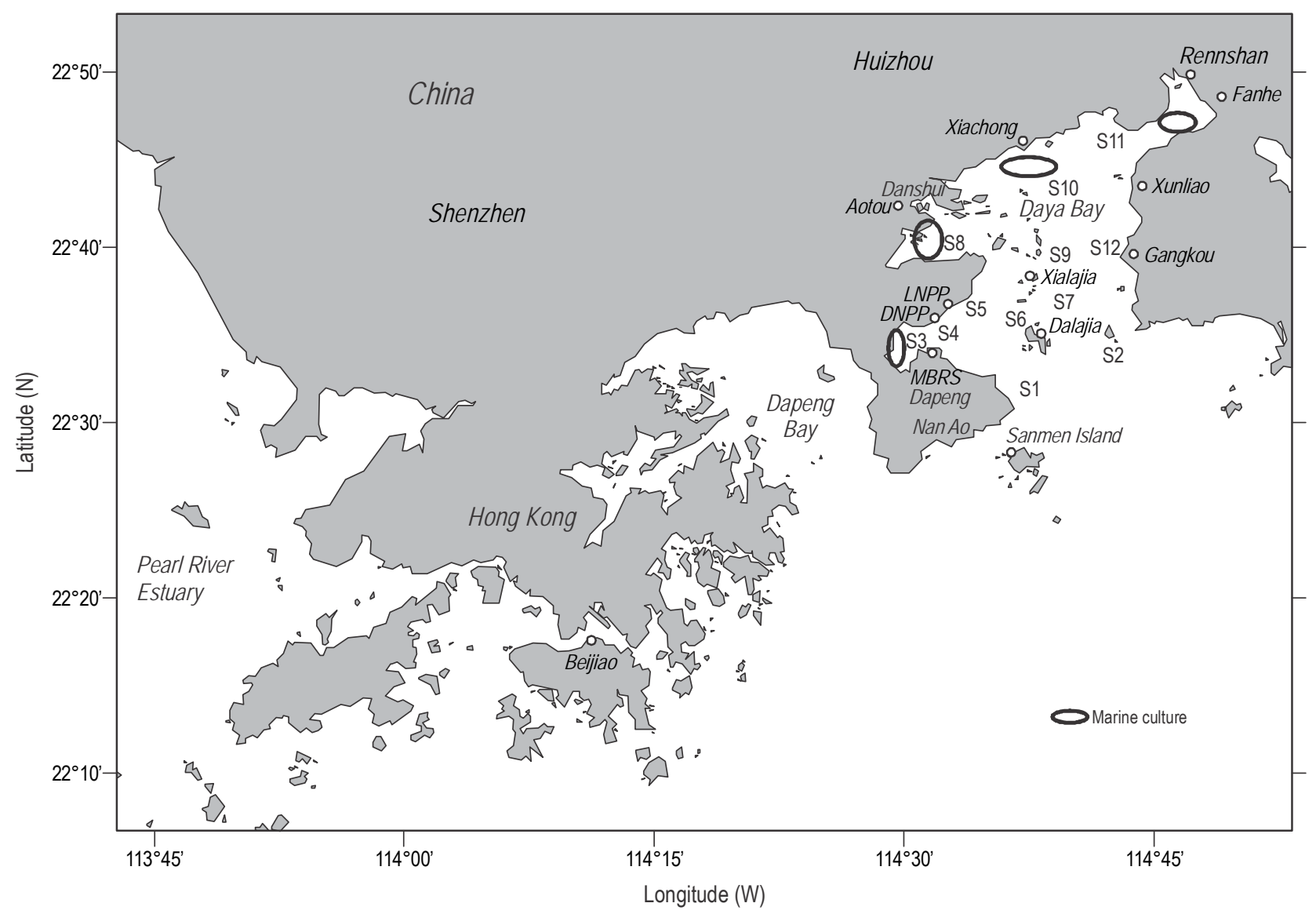

Figure 1. Study area and location of sampling stations (S3 and S8 are aquaculture sites). The location of two nuclear power plants, Daya Bay Nuclear Power Plant (DNPP) and Lingao Nuclear Power Plant (LNPP), and of the Marine Biology Research Station at Daya Bay (MBRS) is shown.

Figura 1. Área de estudio y ubicación de las estaciones de muestreo (S3 y S8 son sitios de acuicultura). Se muestra la localización de las plantas de energía nuclear de la bahía de Daya (DNPP) y Lingao (LNPP), así como de la Estación de Investigación en Biología Marina (MBRS) en la bahía de Daya.

(Hydrolab Corporation, USA). Seawater samples for the analysis of nutrients, chlorophyll $a\left(\mu \mathrm{g} \mathrm{L}^{-1}\right)$, chemical oxygen demand (mg L $\mathrm{L}^{-1}$ ), and 5-day biochemical oxygen demand (mg L $\mathrm{L}^{-1}$ ) were taken using 5-L GO-FLO bottles. Water samples were analyzed for nitrate $\left(\mathrm{NO}_{3}-\mathrm{N}, \mu \mathrm{mol} \mathrm{L}^{-1}\right)$, nitrite $\left(\mathrm{NO}_{2}-\mathrm{N}, \mu \mathrm{mol} \mathrm{L}{ }^{-1}\right)$, silicate $\left(\mathrm{SiO}_{3}-\mathrm{Si}, \mu \mathrm{mol} \mathrm{L}{ }^{-1}\right)$, ammonium $\left(\mathrm{NH}_{4}-\mathrm{N}, \mu \mathrm{mol} \mathrm{L} \mathrm{L}^{-1}\right)$, phosphorus $\left(\mathrm{PO}_{4}-\mathrm{P}, \mu \mathrm{mol} \mathrm{L}^{-1}\right)$, and total phosphorous ( $\mu \mathrm{mol} \mathrm{L}^{-1}$ ) by spectrophotometry (GB 17378.42007 for Specifications for Oceanographic Survey, China). Dissolved oxygen $\left(\mathrm{mg} \mathrm{L}^{-1}\right)$ was determined using Winkler titrations. Two replicate samples of $1.5 \mathrm{~L}$ from the surface and bottom depths were passed through $0.45-\mu \mathrm{m} \mathrm{GF/F} \mathrm{filters}$ and the filtrate was deep-frozen immediately at $-20^{\circ} \mathrm{C}$. At the end of the cruise, all filters were kept in liquid nitrogen and transported to a shore-based laboratory. Within a week after the sampling, chlorophyll $a$ was extracted in $10 \mathrm{~mL}$ $90 \%$ acetone for $24 \mathrm{~h}$ in the dark, in a refrigerator, and the chlorophyll $a$ concentration was determined with a $10 \mathrm{AU}$ fluorometer (Turner Designs, USA).
$\mathrm{pH}$ y salinidad en la superficie y el fondo con un sistema para el monitoreo de la calidad del agua (Quanta, Hydrolab Corporation, EUA). Las muestras de agua de mar para el ánalisis de nutrientes, clorofila $a\left(\mu \mathrm{g} \mathrm{L} \mathrm{L}^{-1}\right)$, demanda química de oxígeno (mg $\left.\mathrm{L}^{-1}\right)$ y demanda bioquímica de oxígeno a los 5 días $\left(\mathrm{mg} \mathrm{L}^{-1}\right)$ fueron recolectadas con botellas GO-FLO de $5 \mathrm{~L}$. También se determinaron las concentraciones de nitrato $\left(\mathrm{NO}_{3}-\mathrm{N}, \mu \mathrm{mol} \mathrm{L} \mathrm{L}^{-1}\right)$, nitrito $\left(\mathrm{NO}_{2}-\mathrm{N}, \mu \mathrm{mol} \mathrm{L} \mathrm{L}^{-1}\right)$, silicato $\left(\mathrm{SiO}_{3}-\mathrm{Si}, \mu \mathrm{mol} \mathrm{L} \mathrm{L}^{-1}\right)$, amonio $\left(\mathrm{NH}_{4}-\mathrm{N}, \mu \mathrm{mol} \mathrm{L}^{-1}\right)$, fósforo $\left(\mathrm{PO}_{4}-\mathrm{P}, \mu \mathrm{mol} \mathrm{L} \mathrm{L}^{-1}\right)$ y fósforo total $\left(\mu \mathrm{mol} \mathrm{L} \mathrm{L}^{-1}\right)$ mediante espectrofotometría (GB 17378.4-2007, especificación para muestreos oceanográficos, China). El oxígeno disuelto $\left(\mathrm{mg} \mathrm{L}^{-1}\right)$ se determinó con el método de titulación Winkler. Se pasaron dos muestras replicadas de $1.5 \mathrm{~L}$ de agua superficial y del fondo a través de filtros GF/F de $0.45 \mu \mathrm{m}$ y el filtrado se liofilizó inmediatamente a $-20^{\circ} \mathrm{C}$. Todos los filtros se mantuvieron en nitrógeno líquido $\mathrm{y}$ al final del crucero fueron transportados a un laboratorio en tierra. Dentro de una semana después del muestreo, se extrajo la clorofila $a$ con 


\section{Picophytoplankton and bacteria defined by flow cytometry}

Samples for picophytoplankton and bacteria were prefiltered through a $20-\mu m$ mesh netting. Triplicate samples were fixed with formaldehyde ( $2 \%$ final concentration) for $15 \mathrm{~min}$ in 2-mL cryotubes, quick-frozen in liquid nitrogen, and analyzed as soon as possible by a FACSCalibur flow cytometer (Becton Dickinson) equipped with a laser emitting at $488 \mathrm{~nm}$ in the laboratory. To estimate the abundance of the different groups, calibration of the cytometer flow rate was performed daily and a solution of $1-\mu \mathrm{m}$ yellow-green latex beads (Polysciences, USA) was added to $0.5-\mathrm{mL}$ subsamples as an internal standard. Abundances of picophytoplankton were calculated by the ratiometric method from the known amount of added beads, calibrated daily against the yellow-green beads.

The population of heterotrophic bacteria was also identified and enumerated by flow cytometry using a FACScanto flow cytometer (Becton Dickinson). Bacteria were then split into high DNA (HDNA) and low DNA (LDNA) groups using the differences in green fluorescence (Gasol et al. 1999).

Picophytoplankton and bacteria were only collected during the autumn sampling.

\section{Weather data}

Air temperature, sea surface temperature, rainfall, and wind data were obtained from the Meteorological Bureau of Shenzhen Municipality (http://www.szmb.gov.cn/) and Hong Kong Observatory (http://www.hko.gov.hk).

\section{Principal component analysis}

Principal component analysis (PCA) is designed to transform the original variables into new, uncorrelated variables (axes), called the principal components, which are linear combinations of the original variables. The new axes lie along the directions of maximum variance (Shrestha and Kazama 2007). It reduces the dimensionality of the data set by explaining the correlation amongst a large number of variables in terms of a smaller number of underlying factors (principal components) without losing much information (Vega et al. 1998, Helena et al. 2000, Alberto et al. 2001, Li et al. 2009). In this study, PCA identified the seasonal changes of environmental factors and the interaction between environment and biology.

All mathematical and statistical computations were performed using MATLAB 2010a (Mathworks, Inc., USA).

\section{RESULTS}

\section{Environmental factors}

Air temperature, sea surface temperature, and wind data were obtained for Beijiao (Hong Kong, some $40 \mathrm{~km}$ from Daya Bay). Air temperature showed a clear seasonal
$10 \mathrm{~mL}$ de acetona al $90 \%$ durante $24 \mathrm{~h}$ en la oscuridad, en un refrigerador, y se determinaron las concentraciones de clorofila $a$ con on fluorómetro 10AU (Turner Designs, EUA).

\section{Detección de picofitoplancton y bacterias mediante citometría de flujo}

Las muestras para la detección de picofitoplancton y bacterias fueron prefiltradas a través de una malla de $20 \mu \mathrm{m}$ de diámetro de poro. Se fijaron muestras triplicadas con formaldehído (2\% de concentración final) durante 15 min en criotubos de $2 \mathrm{~mL}$ y se congelaron rápidamente. Las muestras fueron analizadas lo antes posible mediante un citómetro de flujo FACSCalibur (Becton Dickinson) equipado con un láser que emite a una longitud de onda de $488 \mathrm{~nm}$. Para estimar la abundancia de los diferentes grupos, la calibración de la tasa de flujo se realizó diariamente y se adicionó una solución de bolas pequeñas de látex de color verde amarillo de $1 \mu \mathrm{m}$ (Polysciences, EUA) a submuestras de $0.5 \mathrm{~mL}$ como un estándar interno. La abundancia del picofitoplancton se calculó con el método de enumeración celular (ratiometric) a partir de la cantidad conocida de bolas pequeñas agregadas, calibrada diariamente contra las bolas pequeñas de color verde amarillo.

La identificación y enumeración de la población de bacterias heterotróficas se realizó con un citómetro de flujo FACScanto (Becton Dickinson). Las bacterias se dividieron en dos grupos, uno con mayor cantidad de ADN (MaADN) y el otro con menor cantidad de ADN (MeADN), con base en la diferencia en fluorescencia verde (Gasol et al. 1999).

Sólo se recolectaron muestras de picofitoplancton y bacterias en el otoño.

\section{Datos climáticos}

Se obtuvieron datos climáticos de la temperatura del aire, temperatura superficial del mar, precipitación pluvial, y velocidad y dirección del viento de la Oficina Meteorológica de la Municipalidad de Shenzhen (http://www.szmb.gov.cn/) y el Observatorio de Hong Kong (http://www.hko.gov.hk).

\section{Análisis de componentes principales}

Un análisis de componentes principales (PCA por sus siglas en inglés) está diseñado para transformar las variables originales en variables nuevas no correlacionadas (ejes), llamadas componentes principales, que son combinaciones lineales de las variables originales. Los ejes nuevos reflejan las direcciones de varianza máxima (Shrestha y Kazama 2007). El PCA reduce la dimensionalidad del conjunto de datos al explicar la correlación entre un gran número de variables en términos de un número menor de factores subyacentes (componentes principales) sin perder mucha información (Vega et al. 1998, Helena et al. 2000, Alberto et al. 2001, Li et al. 2009). En el presente trabajo, el 
variation, with the highest value $\left(32.3^{\circ} \mathrm{C}\right)$ recorded in July and August and the lowest $\left(12.5^{\circ} \mathrm{C}\right)$ in January (fig. 2a). Surface water temperature also showed a clear seasonal change, with minimum $\left(16.8^{\circ} \mathrm{C}\right)$ in February and maximum $\left(27.5^{\circ} \mathrm{C}\right)$ in October (fig. 2b). The prevailing winds (about $2.8 \mathrm{~m} \mathrm{~s}^{-1}$ ) were southerly from May to November, and northerly to northwesterly from December to March (fig. 2c).

Monthly rainfall showed the distinct seasonal pattern: abundant rainfall from May to October and less rainfall from October to March (fig. 2d). The average annual precipitation in Daya Bay was $1827 \mathrm{~mm}$, with a maximum monthly rainfall of $370 \mathrm{~mm}$ in August and a minimum of $30 \mathrm{~mm}$ in December.

The PCA applied to the environmental factors distinguished three main groups (northeast monsoon period/winter, southwest monsoon period/summer, and monsoon transition period/spring and autumn) surrounding the first and second component axes, thus explaining $40.67 \%$ of the variance. The temperature, chlorophyll $a$, and phosphate loadings are positive in the first principal component (PC1), while salinity, $\mathrm{SiO}_{3}-\mathrm{Si}$, and $\mathrm{NO}_{3}-\mathrm{N}$ are negative in PC1 (fig. 3). The PCA biplot based on PC1 and the second principal component (PC2) demonstrated the relationship between the monitoring seasons and environmental factors (fig. 3). The three main sampling seasons (northeast monsoon, southwest monsoon, and monsoon transition) clustered together. The northeast monsoon was associated with high salinity, the monsoon transition group occurs in the middle of PC1 and PC2, and the southwest monsoon showed its association with high temperature and chlorophyll $a$.

\section{Nutrient distribution}

The surface and bottom distributions of $\mathrm{SiO}_{3}$-Si increased from the northern part to the mouth of Daya Bay (fig. 4a, b). The distribution of $\mathrm{PO}_{4}-\mathrm{P}$, however, was opposite to that of $\mathrm{SiO}_{3}-\mathrm{Si}$ (fig. 4c, d). The spatial distribution of $\mathrm{NO}_{3}-\mathrm{N}$ showed that the concentration decreased from the eastern to the western part of the bay (fig. 4e, f).

\section{Biological response}

\section{Picophytoplankton}

The picophytoplankton community in Daya Bay was mainly composed of Synechococcus and picoeukaryotes. Synechococcus abundance ranged from $2.16 \times 10^{4}$ to $1.45 \times$ $10^{5}$ cell $\mathrm{mL}^{-1}$ (fig. 5a, b). There was no general difference in Synechococcus abundance between the surface and bottom waters in the bay, although there was a trend towards higher abundance at S3 and S11. There were no significant differences $(P>0.05)$ in picophytoplankton abundance between the surface and bottom depths. Synechococcus abundance was highest at S3.
PCA identificó los cambios estacionales de los factores ambientales y la interacción entre el ambiente y la biología.

Los cálculos matemáticos y estadísticos se realizaron con el programa MATLAB 2010a (Mathworks, Inc., EUA).

\section{Resultados}

\section{Factores ambientales}

Se usaron los datos de temperatura del aire, temperatura superficial del mar y viento proporcionados para Beijiao (Hong Kong, unos $40 \mathrm{~km}$ de la bahía de Daya). La temperatura del aire mostró una clara variación estacional, registrándose el valor más alto $\left(32.3^{\circ} \mathrm{C}\right)$ en julio y agosto y el menor $\left(12.5^{\circ} \mathrm{C}\right)$ en enero (fig. 2a). La temperatura superficial del mar también mostró una clara variación estacional, siendo mayor $\left(27.5^{\circ} \mathrm{C}\right)$ en octubre y menor $\left(16.8^{\circ} \mathrm{C}\right)$ en febrero (fig. 2b). Los vientos del sur (alrededor de $2.8 \mathrm{~m} \mathrm{~s}^{-1}$ ) predominaron entre mayo y noviembre y los del norte y noroeste, entre diciembre y marzo (fig. 2c).

La precipitación pluvial mensual mostró un claro patrón estacional: precipitación abundante de mayo a octubre y menor precipitación de octubre a marzo (fig. 2d). La precipitación media anual en la bahía de Daya fue 1827 mm, con una precipitación mensual máxima de $370 \mathrm{~mm}$ en agosto y mínima de $30 \mathrm{~mm}$ en diciembre.

El PCA para los factores ambientales distinguió tres grupos principales (el periodo del monzón del noreste/invierno, el periodo del monzón del suroeste/verano, y el periodo de transición entre monzones/primavera y otoño) alrededor de los ejes del primer componente principal (PC1) y el segundo componente principal (PC2), explicando $40.67 \%$ de la varianza. Las cargas de temperatura, clorofila $a$ y fosfato fueron positivas en $\mathrm{PC} 1$, mientras que las de salinidad, $\mathrm{SiO}_{3}$-Si y $\mathrm{NO}_{3}-\mathrm{N}$ fueron negativas en PC1 (fig. 3). El diagrama de dispersión biespacial basado en PC1 y PC2 mostró la relación entre las temporadas de muestreo y los factores ambientales (fig. 3). Los tres principales periodos (monzón del noreste, monzón del suroeste y de transición) se agruparon. El monzón del noreste se relacionó con una alta salinidad, el grupo de datos del periodo de transición se encuentra en el medio de PC1 y PC2, y el monzón del suroeste se relacionó con altas temperaturas y niveles de clorofila $a$.

\section{Distribución de nutrientes}

La distribución de $\mathrm{SiO}_{3}$-Si en la superficie y el fondo incrementó desde la parte norte hacia la boca de la bahía de Daya (fig. 4a, b), mientras que la distribución de $\mathrm{PO}_{4}-\mathrm{P}$ es opuesta a la de $\mathrm{SiO}_{3}-\mathrm{Si}$ (fig. 4c, d). La distribución de $\mathrm{NO}_{3}-\mathrm{N}$ disminuyó de la parte este hacia la parte oeste de la bahía (fig. 4e, f). 

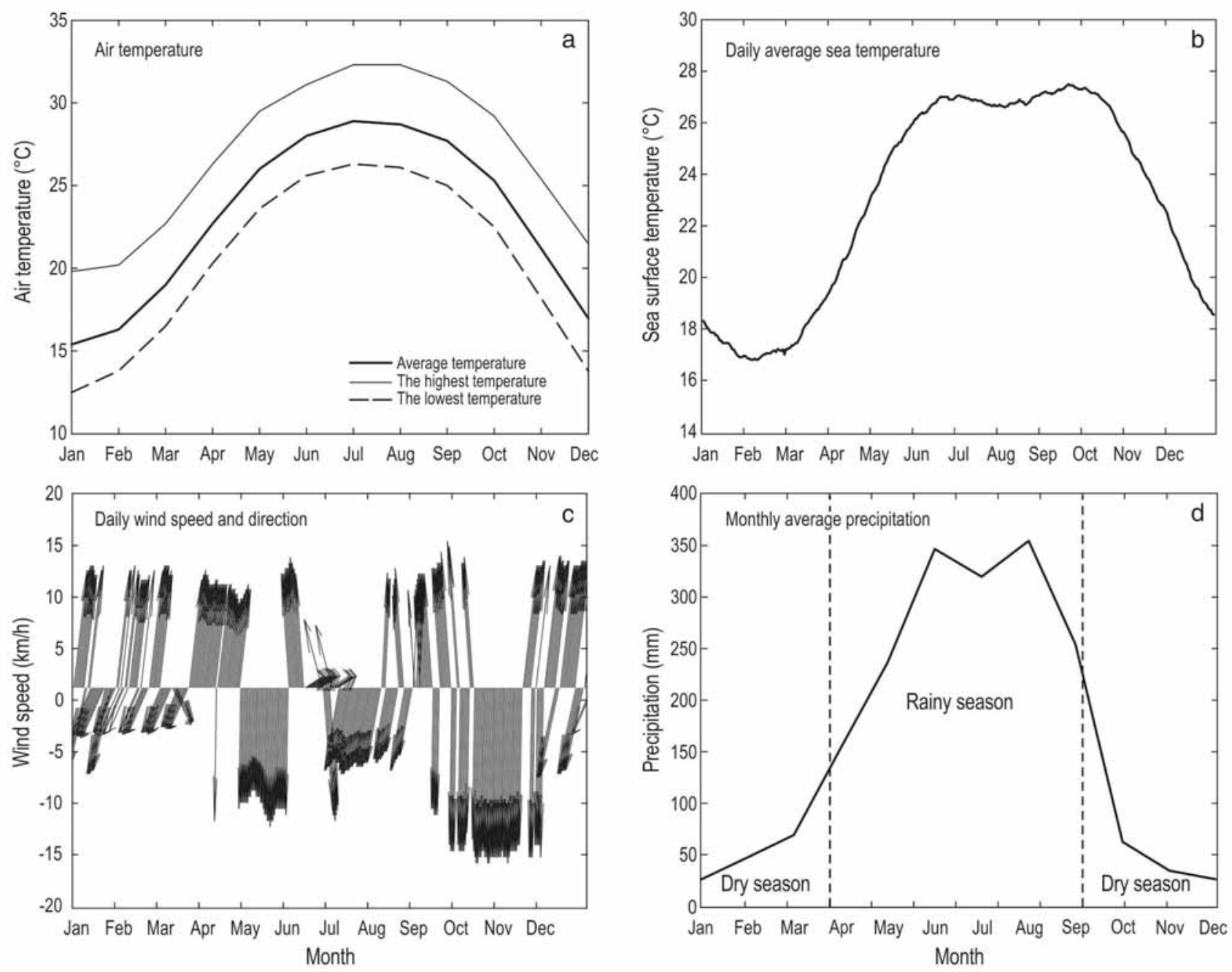

Figure 2. Average weather conditions from 1981 to 2010 near the study area: (a) air temperature, (b) sea surface temperature, (c) wind speed and direction, and (d) rainfall. Air temperature, wind, and sea surface temperature data were obtained for Beijiao, about $40 \mathrm{~km}$ from Daya Bay.

Figura 2. Condiciones climáticas promedio para el periodo de 1981 a 2010 cerca de la zona de estudio: (a) temperatura del aire, (b) temperatura superficial del mar, (c) velocidad y dirección del viento y (d) precipitación pluvial. Los datos de la temperatura del aire y mar y del viento son para Beijiao, a unos 40 km de la bahía de Daya.

The abundance of picoeukaryotes was lower than that of Synechococcus in the bay. The abundance of picoeukaryotes ranged from $0.78 \times 10^{3}$ to $7.95 \times 10^{3}$ cell $\mathrm{mL}^{-1}$ (fig. 5c, d). The spatial distribution of picoeukaryote abundance was similar to that of Synechococcus.

\section{Bacteria}

Bacterial abundance in surface water was generally high in the southwest part of the bay (S3), reaching $2.73 \times 10^{6}$ cell $\mathrm{mL}^{-1}$ (fig. 6a). The lowest abundances of $4.51 \times 10^{5}$ cell $\mathrm{mL}^{-1}$ occurred in the central, southern, and eastern parts of the bay (S1, S2, S7, and S12). Bacterial abundance in bottom water was comparatively higher than in surface water except at S3

\section{Respuesta biológica}

\section{Picofitoplancton}

La comunidad de picofitoplancton en la bahía de Daya estuvo principalmente compuesta por Synechococcus y picoeucariontes. La abundancia de Synechococcus varió de $2.16 \times 10^{4}$ a $1.45 \times 10^{5}$ cél $\mathrm{mL}^{-1}$ (fig. 5a, b). No se encontró una diferencia general entre la abundancia de Synechococcus en la superficie y el fondo de la bahía, aunque se observó una tendencia a una mayor abundancia en S3 y S11. No se observaron diferencias significativas $(P>0.05)$ entre la abundancia de picofitoplancton en la superficie y el fondo. La abundancia de Synechococcus fue mayor en S3. 

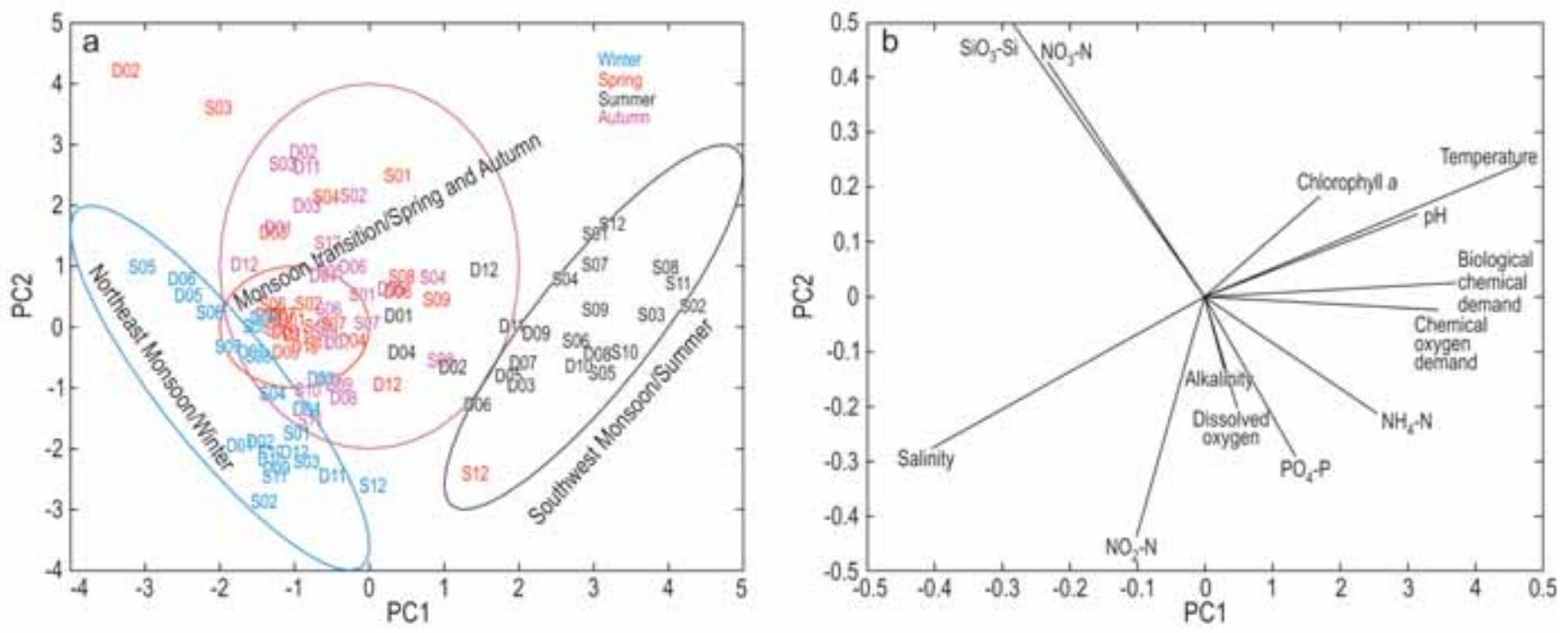

Figure 3. Principal component analysis of the selected environmental variables at the sampled stations in Daya Bay: (a) scores for sampling stations and (b) variable loadings. S and D denote surface and bottom layers, respectively.

Figura 3. Análisis de componentes principales de las variables ambientales de las estaciones de muestreo en la bahía de Daya: (a) puntuaciones de las estaciones de muestreo y (b) cargas de las variables. S y D indican la superficie y el fondo, respectivamente.

and S4 (fig. 6b). There were no significant differences in total bacterial abundance between the surface and bottom depths ( $n=12, P=0.07)$. Bacterial communities observed at the monitoring stations were characterized by one LDNA population and one HDNA population. The lowest LDNA abundance was observed in the central part of the bay (fig. 6c, d). No significant differences were observed in LDNA abundances between surface (mean: $7.06 \times 10^{5}$ cell $\mathrm{mL}^{-1}$ ) and bottom (mean: $5.88 \times 10^{5}$ cell $\mathrm{mL}^{-1}$ ) waters $(P>0.05)$. High HDNA abundances were observed in the western and northern parts of the bay (fig. 6e, f). In general, the abundance of HDNA bacteria in surface water (mean: $5.88 \times 10^{5}$ cell mL$^{-1}$ ) was greater than in bottom water (mean: $3.74 \times 10^{5}$ cell $\left.\mathrm{mL}^{-1}\right)$, with significant difference $(P=0.05)$. No significant difference $(P>0.05)$ between LDNA and HDNA abundances was observed in surface and bottom water.

\section{Principal component analysis}

The PCA for picophytoplancton vs environmental factors and bacteria vs environmental factors was used to identify key environmental variables that could explain the picophytoplankton (Synechococcus and picoeukaryotes) and bacterial (HDNA and LDNA) abundances, respectively. For picophytoplankton, PC1, which explained $49.21 \%$ of the variation of the environmental data, was highly correlated with Synechococcus and nutrients (fig. 7a). PC2 explained 21.24\% of the variation and was highly correlated with $\mathrm{PO}_{4}-\mathrm{P}$ and $\mathrm{NO}_{2}-\mathrm{N}$. Both Synechococcus and picoeukaryotes were positively related to PC1 and negatively related to PC2. From the score plot, the spatial distribution of the samples can be
La abundancia de picoeucariontes fue menor que la de Synechococcus en la bahía. La abundancia de picoeucariontes varió de $0.78 \times 10^{3}$ a $7.95 \times 10^{3}$ cél $\mathrm{mL}^{-1}$ (fig. $5 \mathrm{c}$, d). La distribución espacial de la abundancia de picoeucariontes fue similar a la de Synechococcus.

\section{Bacterias}

La abundancia de bacterias en el agua superficial por lo general fue alta en la parte suroeste de la bahía (S3), alcanzando $2.73 \times 10^{6}$ cél $\mathrm{mL}^{-1}$ (fig. 6a). Se registraron las menores abundancias de $4.51 \times 10^{5}$ cél $\mathrm{mL}^{-1}$ en las partes central, sur y este de la bahía (S1, S2, S7 y S12). La abundancia de bacterias en el fondo de la bahía fue comparativamente mayor que en la superficie excepto en S3 y S4 (fig. 6b). No hubo diferencias significativas entre la abundancia bacteriana total en la superficie y el fondo $(n=12, P=0.07)$. Las comunidades bacterianas observadas en los sitios de muestreo fueron caracterizadas por una población de MaADN y una población de MeADN. La abundancia más baja del grupo de MeADN se registró en la parte central de la bahía (fig. 6c, d), y no se observaron diferencias significativas $(P>0.05)$ entre

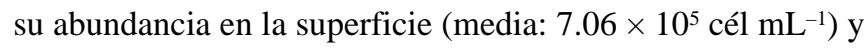
el fondo (media: $5.88 \times 10^{5}$ cél $\mathrm{mL}^{-1}$ ). La abundancia del grupo de MaADN fue mayor en las partes norte y oeste de la bahía (fig. 6e, f) y, en general, fue mayor en la superficie (media: $5.88 \times 10^{5}$ cél $\mathrm{mL}^{-1}$ ) que en el fondo (media: $3.74 \times$ $10^{5}$ cél $\left.\mathrm{mL}^{-1}\right)$, con una diferencia significativa $(P=0.05)$. No hubo diferencias significativas $(P>0.05)$ entre las abundancias de los dos grupos (MeADN y MaADN) en la superficie y el fondo. 

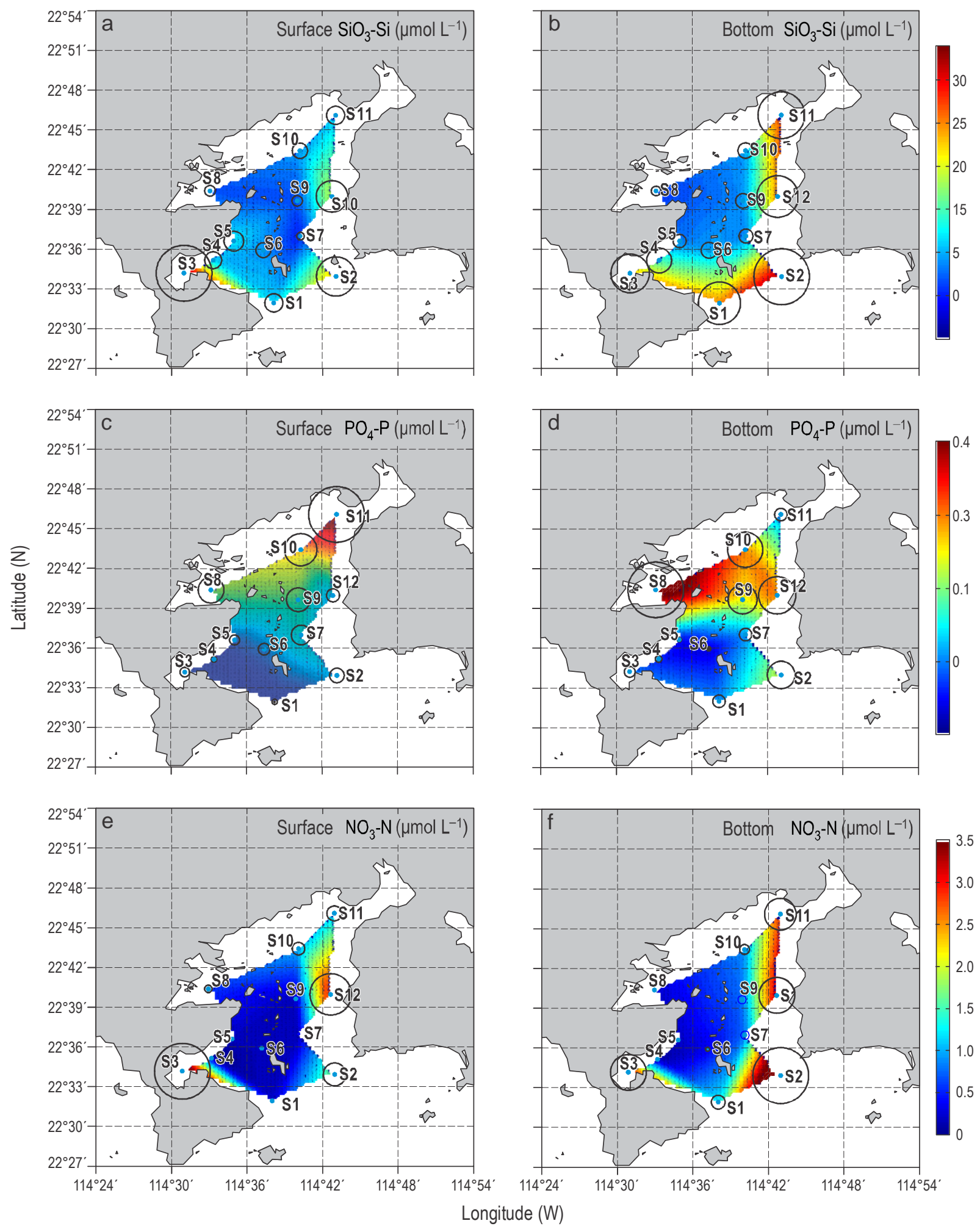

Figure 4. Surface and bottom changes of $\mathrm{SiO}_{3}-\mathrm{Si}(\mathbf{a}, \mathbf{b}), \mathrm{PO}_{4}-\mathrm{P}(\mathbf{c}, \mathbf{d})$, and $\mathrm{NO}_{3}-\mathrm{N}(\mathbf{e}, \mathbf{f})$ in Daya Bay. The circles indicate relative magnitude and the blue dots represent sampling stations.

Figura 4. Cambios de $\mathrm{SiO}_{3}-\mathrm{Si}(\mathbf{a}, \mathbf{b}), \mathrm{PO}_{4}-\mathrm{P}(\mathbf{c}, \mathbf{d})$ y $\mathrm{NO}_{3}-\mathrm{N}(\mathbf{e}, \mathbf{f})$ en la superficie y fondo de la bahía de Daya. Los círculos indican la magnitud relativa y los puntos azules representan las estaciones de muestreo. 

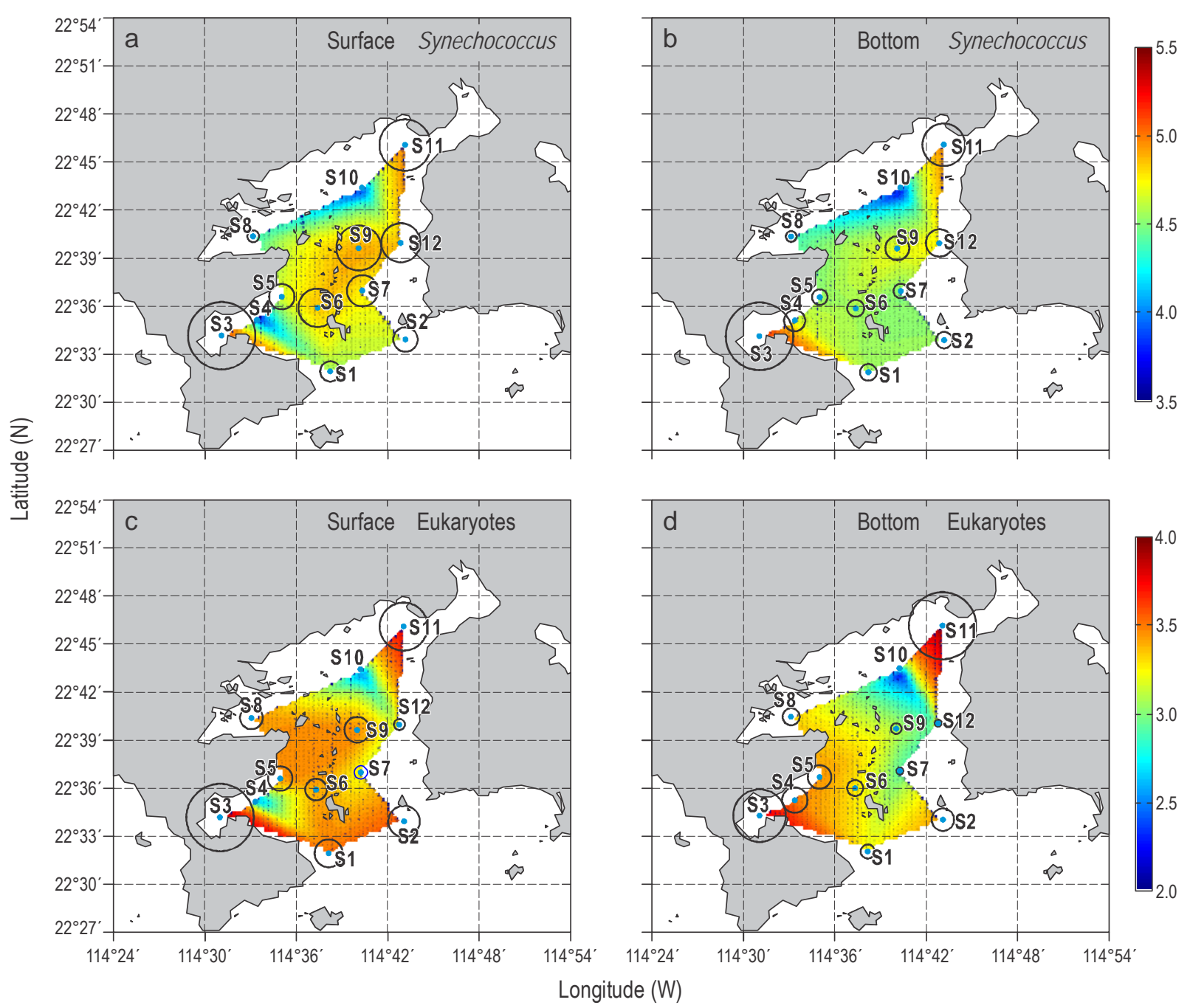

Figure 5. Spatial distribution of the abundance of the picophytoplankton community in Daya Bay: Synechococcus in surface water (a) and bottom water (b); eukaryotes in surface water (c) and bottom water (d). The circles indicate the relative magnitude in the corresponding layer and the blue dots represent the sampling stations. The values of the color bar show the log10 (abundance).

Figura 5. Distribución espacial de la abundancia de la comunidad de picofitoplancton en la bahía de Daya: Synechococcus en la superficie (a) y el fondo (b); eucariontes en la superficie (c) y el fondo (d). Los círculos indican la magnitud relativa en la capa correspondiente y los puntos azules representan las estaciones de muestreo. Los valores de la barra de color muestran el log10 (abundancia).

observed clearly (fig. 7b). Three stations (S3, S11, and S12) were located in the western and eastern parts of the bay. The scores of these stations were positive in PC1. The two stations (S8 and S9) located around the central and northwest parts of the bay clustered. The scores of the rest of the stations (S1, S2, and S4-S7) located around the mouth and in the central part of the bay were negative and positive in PC2.

For bacteria, the first two principle components explained $50.39 \%$ of the variance in the environmental data (fig. 8a). PC1 was positively associated with $\mathrm{SiO}_{3}-\mathrm{Si}, \mathrm{NO}_{3}-\mathrm{N}, \mathrm{NH}_{4}-\mathrm{N}$, HDNA, and LDNA, and explained $27.81 \%$ of the total variance in the original variables. PC2 was associated with $\mathrm{NO}_{2}-\mathrm{N}$ and $\mathrm{PO}_{4}-\mathrm{P}$, and explained $22.58 \%$ of the total variance. Both HDNA and LDNA were positively related to PC1

\section{Análisis de componentes principales}

El PCA para picofitoplancton vs factores ambientales y bacterias $v s$ factores ambientales se usó para identificar las variables ambientales clave que podrían explicar las abundancias de picofitoplancton (Synechococcus y picoeucariontes) y bacterias (MaADN y MeADN), respectivamente. Para el picofitoplancton, PC1 explicó $49.21 \%$ de la varianza y presentó una alta correlación con Synechococcus y los nutrientes (fig. 7a). El PC2 explicó $21.24 \%$ de la varianza y se correlacionó altamente con $\mathrm{PO}_{4}-\mathrm{P}$ y $\mathrm{NO}_{2}-\mathrm{N}$. Tanto Synechococcus como los picoeucariontes se relacionaron positivamente con PC1 y negativamente con PC2. La distribución espacial de las muestras se puede observar claramente en la gráfica de 

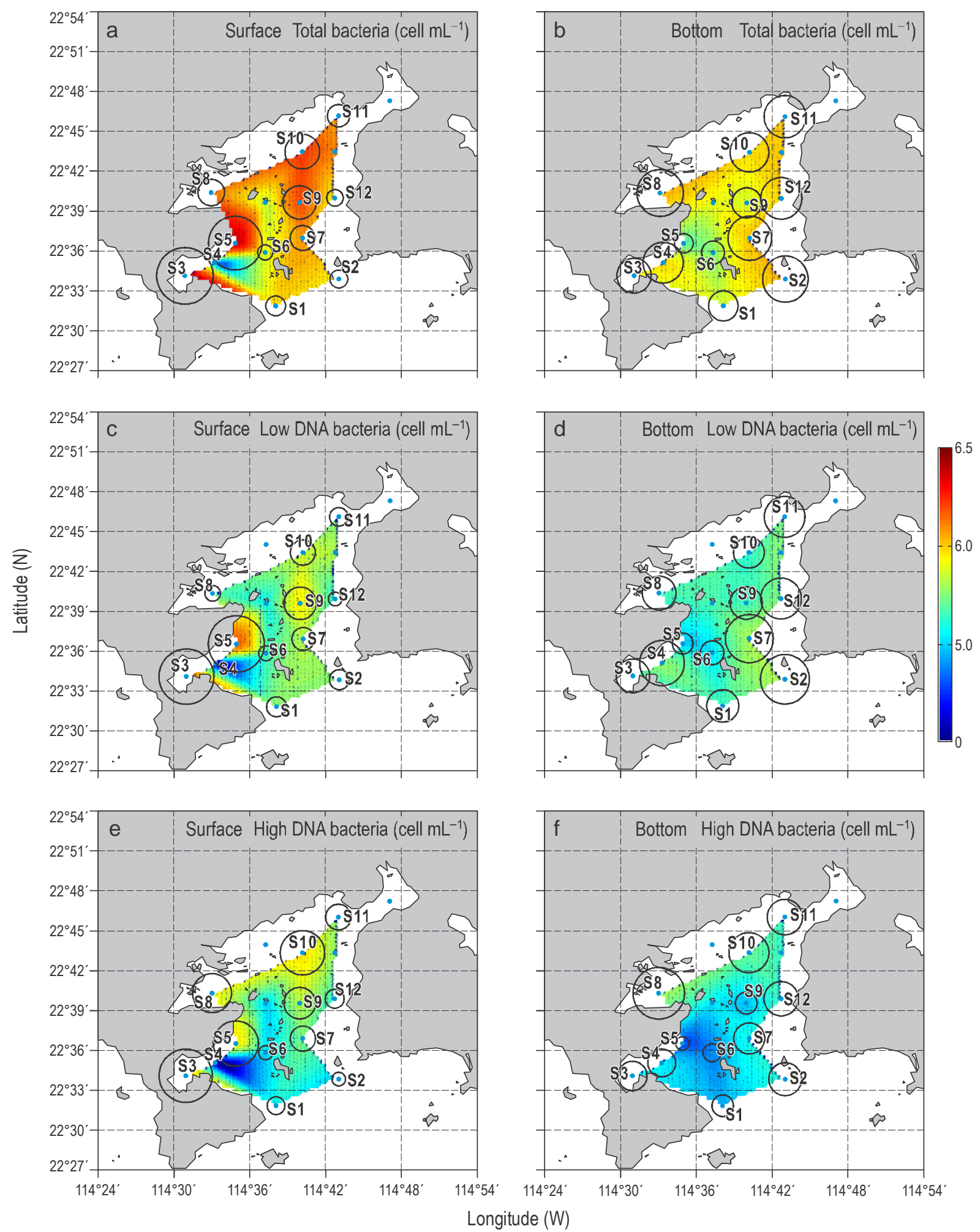

Figure 6. Spatial distribution of the abundance of bacteria in Daya Bay: total bacteria in surface water (a) and bottom water (b); low DNA bacteria in surface water (c) and bottom water (d); high DNA bacteria in surface water (e) and bottom water (f). The circles indicate the relative magnitude in the corresponding layer and the blue dots represent sampling stations. The values of the color bar show the log 10 (abundance).

Figura 6. Distribución espacial de la abundancia de bacterias en la bahía de Daya: bacterias totales en la superficie (a) y el fondo (b); bacterias con menor cantidad de ADN en la superficie (c) y el fondo (d); bacterias con mayor cantidad de ADN en la superficie (e) y el fondo (f). Los círculos indican la magnitud relativa en la capa correspondiente y los puntos azules representan las estaciones de muestreo. Los valores de la barra de color muestran el log10 (abundancia). 

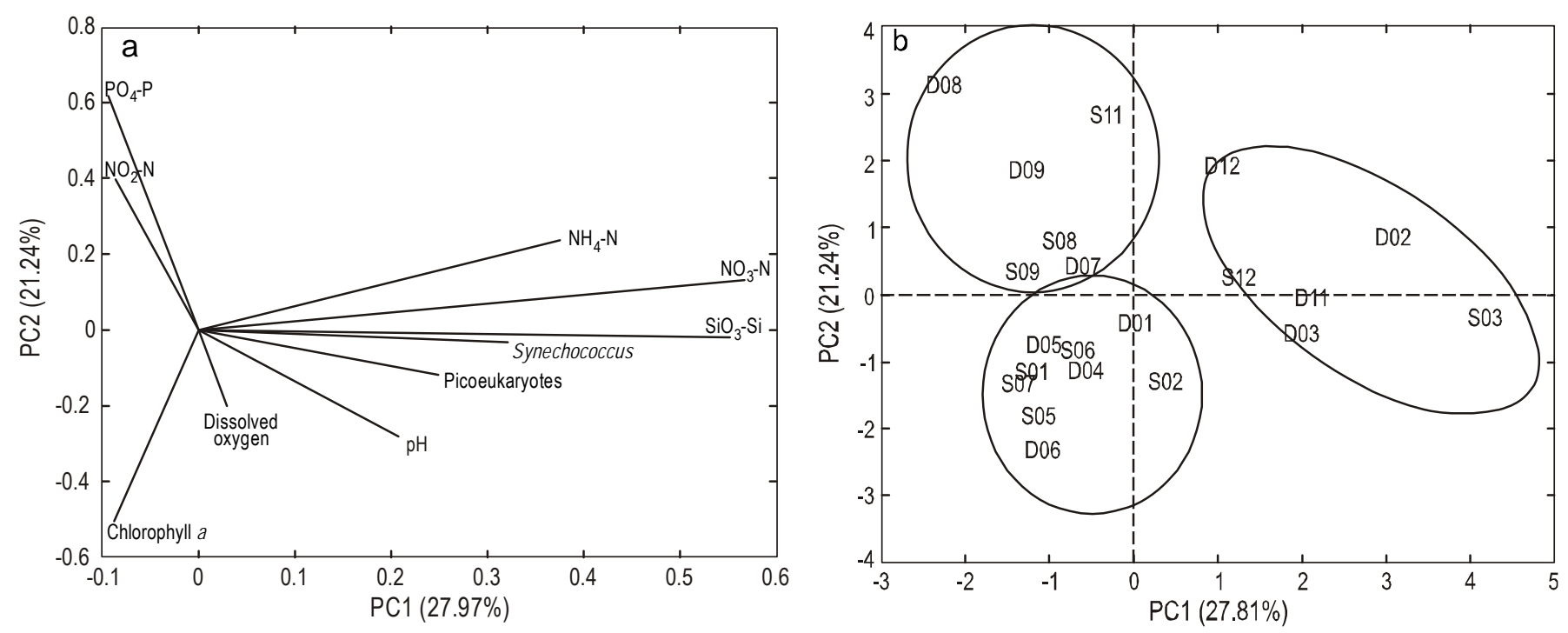

Figure 7. (a) Variable loadings (environmental factors plus picophytoplankton) for the 12 sampling stations in the first two principal components, PC1 and PC2, and (b) score plots for PC1 and PC2 obtained for the 12 stations. S and D denote surface and bottom layers, respectively.

Figura 7. (a) Cargas de las variables (factores ambientales más picofitoplancton) para las 12 estaciones de muestreo de los primeros dos componentes principales, PC1 y PC2, y (b) puntuaciones para PC1 and PC2 para las 12 estaciones. S y D indican la superficie y el fondo, respectivamente.

and PC2. The spatial pattern is similar to the PCA results for picophytoplankton and environmental factors (fig. 8b).

\section{DISCUSSION}

Daya Bay is located in a tropical region. The winds change direction from southwest to northeast or vice versa. The wet (southwest) monsoon brings clean air into the region from June to October. Conversely, the dry (northeast) monsoon predominates from November through April. To a great extent, the seasonal changes of the hydrodynamics in the bay are determined by Southeast Asian monsoons. Lower temperature and high salinity water intrudes into the bay along the bottom from the South China Sea under the influence of the weak southwest monsoon from May to September (Han 1998, Ji and Huang 1990, Wu et al. 2010). On the contrary, in Daya Bay the water column is vertically mixed under the influence of the northeast monsoon (Chen and Li 1996). In the study, the hydrodynamics in autumn shows interesting transit characteristics, from stratification in summer to wellmixed conditions in winter.

Spatially heterogeneous microbial communities were a regular feature of the subtropical embayment investigated in this study. However, two types of sites (marine aquaculture and coastal water) encapsulated the heterogeneity within the bay. The structure of microbial communities within the two distinct groups appeared likely to be driven by a combination of three prominent characteristics of this environment: highly localized marine aquaculture, physical forcing due to wind convection, and complex bay topography. puntuaciones (fig. 7b). Tres estaciones (S3, S11 y S12) se localizaron en las partes oeste y este de la bahía, y sus puntuaciones fueron positivas en PC1. Las dos estaciones (S8 y S9) ubicadas en las partes central y noroeste de la bahía se agruparon. Las puntuaciones de las demás estaciones (S1, S2 y S4-S7) en la boca y parte central de la bahía fueron negativas y positivas en PC2.

Para las bacterias, los primeros dos componentes principales explicaron $50.39 \%$ de la variación de los datos ambientales (fig. 8a). PC1 se asoció positivamente con $\mathrm{SiO}_{3}-\mathrm{Si}$, $\mathrm{NO}_{3}-\mathrm{N}, \mathrm{NH}_{4}-\mathrm{N}, \mathrm{MaADN}$ y MeADN, y explicó $27.81 \%$ de la varianza total de las variables originales. PC2 se asoció con $\mathrm{NO}_{2}-\mathrm{N}$ y $\mathrm{PO}_{4}-\mathrm{P}$, y explicó $22.58 \%$ de la varianza total. Tanto MaADN como MeADN se relacionaron positivamente con PC1 y PC2. El patrón espacial es similar a la de los resultados del PCA para el picofitoplancton y los factores ambientales (fig. 8b).

\section{DisCUSIÓN}

La bahía de Daya se localiza en una región tropical. Los vientos cambian de dirección del suroeste al noreste o viceversa. El monzón lluvioso (monzón del suroeste) trae aire limpio a la región de junio a octubre. El monzón seco (monzón del noreste) predomina de noviembre a abril. Los cambios estacionales de la hidrodinámica de la bahía son en gran medida determinados por los monzones del Sureste de Asia. Agua de menor temperatura y mayor salinidad del mar de China Meridional entra a la bahía por el fondo entre mayo y septiembre durante la influencia del monzón más débil del 

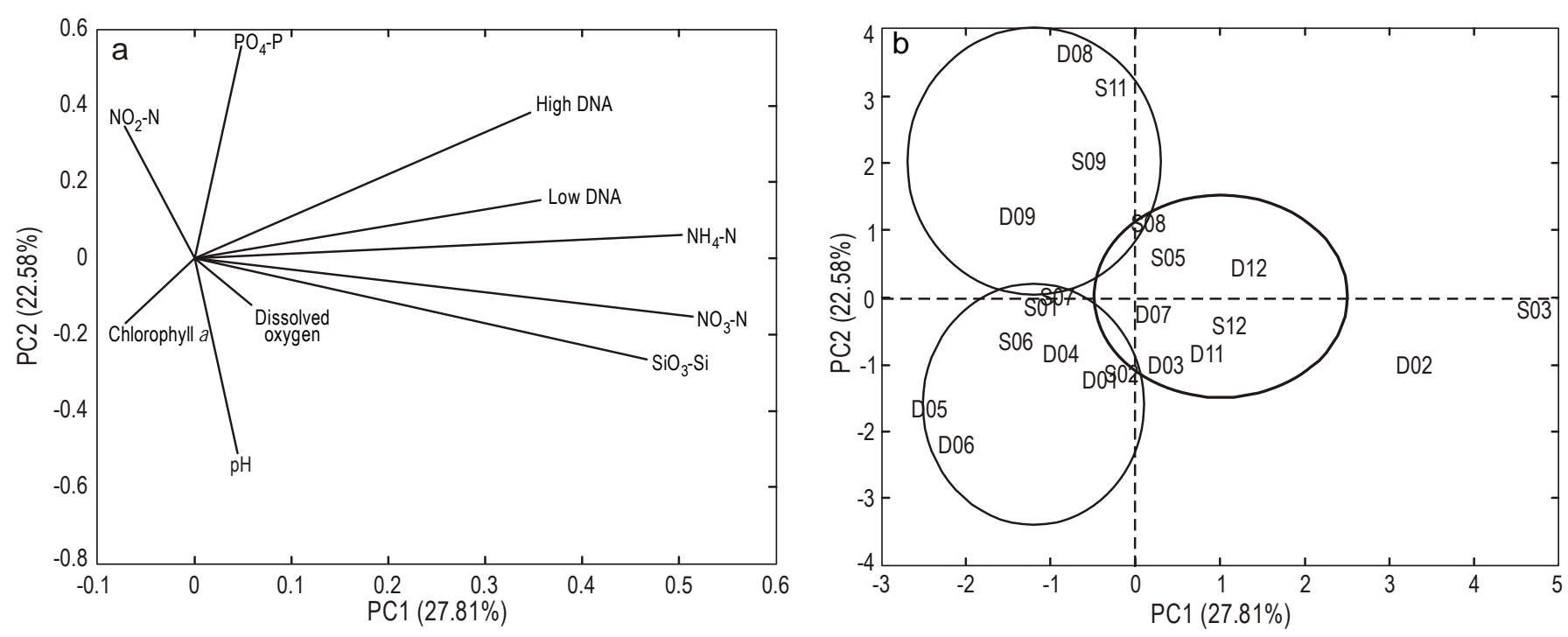

Figure 8. (a) Variable loadings (environmental factors plus bacteria) for the 12 sampling stations in the first two principal components, PC1 and PC2, and (b) score plots for PC1 and PC2 obtained for the 12 stations. S and D denote surface and bottom layers, respectively.

Figura 8. (a) Cargas de las variables (factores ambientales más bacterias) para las 12 estaciones de muestreo de los primeros dos componentes principales, PC1 y PC2, y (b) puntuaciones para PC1 y PC2 para las 12 estaciones. S y D indican la superficie y el fondo, respectivamente.

Generally, Prochlorococcus dominates in the subtropical oligotrophic oceans (Goericke and Welschmeyer 1993, Campbell et al. 1994), whilst Synechococcus is usually more abundant under intermediate nutrient conditions (Liu et al. 1997). Synechococcus is more abundant in plume-influenced and coastal waters, while Prochlorococcus was dominant in the oligotrophic water of the Mississippi River plume and its adjacent waters (Liu et al. 2004). Synechococcus cell density typically ranges from $10^{2}$ to $10^{5}$ cells $\mathrm{mL}^{-1}$ in temperate estuaries and often exceeds $10^{6}$ cells $\mathrm{mL}^{-1}$ in subtropical regions (Wang et al. 2011). Synechococcus is the most abundant group in various coastal ecosystems, including Chesapeake Bay (Wang et al. 2011), San Francisco Bay (Ning et al. 2000), and Florida Bay (Phlips et al. 1999). In this study, Prochlorococcus was found in very low abundances. On the contrary, Synechococcus dominated in the bay (fig. 5). Nutrient availability might determine Synechococcus growth (Chen et al. 2007). The scores for S3, S11, and S12 are mainly due to Synechococcus, picoeukaryotes, $\mathrm{NO}_{3}-\mathrm{N}$, and $\mathrm{SiO}_{3}-\mathrm{Si}$ in PC2. In fact, Synechococcus abundance at these stations is higher than that at the rest of the stations (fig. 7). The scores for these stations located in the western and eastern parts of the bay are different from those at the mouth and northern part of the bay in PC1.

The correlations between the abundance of picoeukaryotes and the environmental factors for Daya Bay were similar to those between the abundance of prokaryotic cells (Synechococcus) and the environmental factors (fig. 7). The similar spatial distribution pattern between prokaryotic cells and picoeukaryotes strongly suggested similar ecological niches in Daya Bay, which contrasts to the previously suroeste (Han 1998, Ji y Huang 1990, Wu et al. 2010). Al contrario, bajo la influencia del monzón del noreste, la columna de agua en la bahía de Daya se mezcla verticalmente (Chen y Li 1996). En el presente estudio se encontró que la hidrodinámica en otoño muestra características de transición interesantes, desde estratificación en verano hasta condiciones de mezcla intensa en invierno.

Las comunidades microbianas espacialmente heterogéneas fueron una característica regular de la bahía subtropical bajo estudio; sin embargo, dos tipos de sitios (acuicultura marina y agua costera) denotaron la heterogeneidad dentro de la bahía. La estructura de las comunidades microbianas en los dos grupos distintos probablemente se debe a una combinación de tres características prominentes de este ambiente: acuicultura marina muy localizada, forzamiento físico por la convección del viento y la topografía compleja de la bahía.

En general, Prochlorococcus predomina en aguas oligotróficas subtropicales (Goericke y Welschmeyer 1993, Campbell et al. 1994), mientras que Synechococcus tiende a ser más abundante en aguas con concentraciones intermedias de nutrientes (Liu et al. 1997). Synechococcus es más abundante en aguas costeras influenciadas por lenguetas, pero Prochlorococcus predominó en las aguas oligotróficas de la lengueta del río Mississippi y sus aguas adyacentes (Liu et al. 2004). La densidad celular de Synechococcus típicamente varía de $10^{2}$ a $10^{5}$ cél $\mathrm{mL}^{-1}$ en estuarios templados y frecuen-

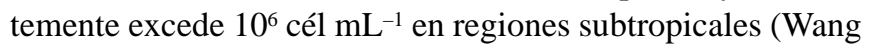
et al. 2011). Synechococcus es el grupo más abundante en varios ecosistemas costeros, incluyendo las bahías de Chesapeake (Wang et al. 2011), San Francisco (Ning et al. 2000) y Florida (Phlips et al. 1999). En la bahía de Daya, la 
reported distinct ecological niches in different ecosystems, such as the Pearl River Estuary (Zhang et al. 2013). A significant positive correlation was observed between $\mathrm{NO}_{3}-\mathrm{N}$, $\mathrm{NH}_{4}-\mathrm{N}$, and $\mathrm{SiO}_{3}-\mathrm{Si}$ concentrations, and Synechococcus and picoeukaryotes abundances (fig. 7). Within the Daya Bay system, the control of picophytoplankton abundance is likely to be driven by bottom-up processes (nutrient) and top-down processes (grazing).

In addition, the similar spatial pattern between the LDNA and HDNA groups may indicate that they may be better adapted to productive coastal waters, hence suggesting a niche partitioning between the similar bacterial groups. However, bacterial abundance in the eastern, northern, and western parts of the bay is slightly higher than in the rest of the areas (fig. 8). Our results suggest that the HDNA and LDNA groups may possess their own environmental niche with favorable conditions for them. The spatial differences in variability in bacterial abundance (HDNA and LDNA) may be due to system-specific changes in environmental parameters.

In summary, despite the important role of picophytoplankton and heterotrophic bacteria in the microbial dynamics of coastal bays, there is still a critical lack of information on their community composition and dynamics. Abiotic environments may determine the dynamics of phytoplankton and bacteria. Generally, abundances of picophytoplankton and heterotrophic bacteria have a similar spatial distribution. A significant positive correlation was observed between nutrients and Synechococcus and picoeukaryotes in the present work. Picophytoplankton abundance is likely to be driven by bottom-up processes (nutrient) and top-down processes (grazing). Nutrients may control the spatial distribution of bacteria. HDNA and LDNA bacterial groups may possess their own environmental niche with favorable conditions for them. Thus, biological activities may be due to systemspecific changes in environmental parameters.

\section{ACKNOWLEDGMENTS}

This research was supported by the National Natural Science Foundation of China (projects No. 31270528 and No. 41206082); the Key Laboratory for Ecological Environment in Coastal Areas, State Oceanic Administration (No. 201211); and Key Laboratory of Marine Ecology and Environmental Science and Engineering, State Oceanic Administration (MESE-2013-02). The authors thank Jianlin Zhang for the flow cytometry analyses, the staff of the Marine Biology Research Station at Daya Bay (Chinese Academy of Sciences) for providing support and help, and the information system of China Ecosystem Research Network.

\section{REFERENCES}

Alberto WD, Del Pilar DM, Valeria AM, Fabiana PS, Cecilia HA, De Los Angeles BM. 2001. Pattern recognition techniques for abundancia de Prochlorococcus fue baja y Synechococcus predominó (fig. 5). La disponibilidad de nutrientes influye en el crecimiento de Synechococcus (Chen et al. 2007). Las puntuaciones para S3, S11 y S12 se deben principalmente a la presencia de Synechococcus, picoeucariontes, $\mathrm{NO}_{3}-\mathrm{N}$ y SiO${ }_{3}^{-}$ $\mathrm{Si}$ en PC2. De hecho, la abundancia de Synechococcus en estas estaciones es mayor que en las demás estaciones (fig. 7). Las puntuaciones para estas estaciones localizadas en las partes oeste y este son diferentes a las de las estaciones en la boca y parte norte de la bahía en PC1.

Las correlaciones entre la abundancia de picoeucariontes y los factores ambientales para la bahía Daya fueron similares a las correlaciones entre la abundancia de células procariotas (Synechococcus) y los factores ambientales (fig. 7). La similitud en el patrón de distribución espacial de las células procariotas y los picoeucariontes sugiere nichos ecológicos similares en la bahía de Daya, lo cual difiere de los distintos nichos ecológicos documentados para otros ecosistemas, como el estuario del río Perla (Zhang et al. 2013). Se observó una correlación positiva significativa entre las concentraciones de $\mathrm{NO}_{3}-\mathrm{N}, \mathrm{NH}_{4}-\mathrm{N}$ y $\mathrm{SiO}_{3}-\mathrm{Si}$ y la abundancia de Synechococcus y picoeucariontes (fig. 7). En el sistema de la bahía de Daya, la abundancia de picofitoplancton parece ser controlada por procesos de abajo a arriba (nutrientes) y de arriba a bajo (pastoreo).

Asimismo, la similitud en el patrón espacial de los dos grupos de bacterias (MaADN y MeADN) podría indicar una mejor adaptación a aguas costeras productivas, lo que sugiere una partición de nichos entre estos grupos similares; sin embargo, la abundancia de bacterias en las partes este, norte y oeste de la bahía es ligeramente mayor que en las otras zonas (fig. 8). Nuestros resultados sugieren que los grupos de MaADN y MeADN pueden tener su propio nicho ambiental con condiciones favorables para ellos. Las diferencias espaciales en la variabilidad de la abundancia bacteriana (MaADN y MeADN) se pueden atribuir a cambios en los parámetros ambientales específicos al sistema.

En resumen, a pesar de la importante función del picofitoplancton y las bacterias heterotróficas en la dinámica microbiana de bahías costeras, todavía se carece de información sobre la dinámica y composición de la comunidad. Los ambientes abióticos podrían determinar la dinámica del fitoplancton y las bacterias. En general, las abundancias de picofitoplancton y bacterias heterotróficas presentan una distribución espacial similar. En el presente estudio se observó una importante correlación positiva entre los nutrientes y Synechococcus y picoeucariontes. La abundancia de picofitoplancton parece ser controlada por procesos de abajo a arriba (nutrientes) y de arriba a bajo (pastoreo). Los nutrientes pueden controlar la distribución bacteriana. Los dos grupos de bacterias (MaADN y MeADN) parecen tener sus propios nichos ambientales con condiciones que les favorecen. Por lo tanto, las actividades biológicas pueden deberse a cambios en los parámetros ambientales específicos al sistema. 
the evaluation of spatial and temporal variations in water quality. A case study: Suquia River basin (Cordoba-Argentina). Water Res. 35: 2881-2894.

http://dx.doi.org/10.1016/S0043-1354(00)00592-3

Campbell L, Nolla H, Vaulot D. 1994. The importance of Prochlorococcus to community structure in the central North Pacific Ocean. Limnol. Oceanogr. 39: 954-961.

Chen JS, Li FY. 1996. Characteristics of mineral nitrogens in Daya Bay. Trop. Oceanol. 15: 92-98.

Chen YLL, Chen HY, Lin II, Lee MA, Chang J. 2007. Effects of cold eddy on phytoplankton production and assemblages in Luzon Strait bordering the South China Sea. J. Oceanogr. 63: 671-683. http://dx.doi.org/10.1007/s10872-007-0059-9

Gasol JM, Zweifel UL, Peters F, Fuhrman JA, Hagström Å. 1999. Significance of size and nucleic acid content heterogeneity as measured by flow cytometry in natural planktonic bacteria. Appl. Environ. Microbiol. 65: 4475-4483.

Goericke R, Welschmeyer NA. 1993. The marine prochlorophyte Prochlorococcus contributes significantly to phytoplankton biomass and primary production in the Sargasso Sea. Deep Sea Res. (I Oceanogr. Res. Pap.) 40: 2283-2294. http://dx.doi.org/10.1016/0967-0637(93)90104-B

Han WY. 1998. Marine Chemistry in South China Sea. Science Publishing House, Beijing, China.

Helena B, Pardo R, Vega M, Barrado E, Fernandez JM, Fernandez L. 2000. Temporal evolution of groundwater composition in an alluvial aquifer (Pisuerga River, Spain) by principal component analysis. Water Res. 34: 807-816. http://dx.doi.org/10.1016/S0043-1354(99)00225-0

Ji WD, Huang SG. 1990. Relationship between nutrient variation in Daya Bay water column and hydrographical and biological factors. In: Oceanography, T.I.O. (ed.), Collections of Papers on Marine Ecology in the Daya Bay (II). Ocean Publishing House, Beijing, China, pp. 123-132.

Jickells T. 1998. Nutrient biogeochemistry of the coastal zone. Science 281: 217-222. http://dx.doi.org/10.1126/science.281.5374.217

Li S, Gu S, Tan X, Zhang Q. 2009. Water quality in the upper Han River basin, China: The impacts of land use/land cover in riparian buffer zone. J. Hazard. Mater. 165: 317-324. http://dx.doi.org/10.1016/j.jhazmat.2008.09.123

Liu H, Nolla HA, Campbell L. 1997. Prochlorococcus growth rate and contribution to primary production in the equatorial and subtropical North Pacific Ocean. Aquat. Microb. Ecol. 12: 39-47. http://dx.doi.org/10.3354/ame012039

Liu H, Dagg M, Campbell L, Urban-Rich J. 2004. Picophytoplankton and bacterioplankton in the Mississippi River plume and its adjacent waters. Estuaries 27: 147-156. http://dx.doi.org/10.1007/BF02803568

Ning X, Cloern JE, Cole BE. 2000. Spatial and temporal variability of picocyanobacteria Synechococcus sp. in San Francisco Bay. Limnol. Oceanogr. 45: 695-702.

Phlips EJ, Badylak S, Lynch T.C. 1999. Blooms of the picoplanktonic cyanobacterium Synechococcus in Florida Bay, a subtropical inner-shelf lagoon. Limnol. Oceanogr. 44: 1166-1175.

Shrestha S, Kazama F. 2007. Assessment of surface water quality using multivariate statistical techniques: A case study of the Fuji River basin, Japan. Environ. Model. Software 22: 464-475.

Vega M, Pardo R, Barrado E, Deban L. 1998. Assessment of seasonal and polluting effects on the quality of river water by exploratory data analysis. Water Res. 32: 3581-3592. http://dx.doi.org/10.1016/S0043-1354(98)00138-9

\section{Agradecimientos}

Este trabajo fue apoyado por la Fundación de Ciencias Naturales de China (proyectos No. 31270528 y No. 41206082); el Laboratorio para el Ambiente Ecológico en Zonas Costeras, Administración Oceánica Estatal (proyecto No. 201211); y el Laboratorio de Ecología Marina y Ciencias Ambientales e Ingeniería, Administración Oceánica Estatal (proyecto No. MESE-2013-02). Agradecemos a Jianlin Zhang los análisis de la citometría de flujo, al personal de la Estación de Investigación en Biología Marina en la bahía de Daya (Academia de Ciencias de China) su apoyo y el sistema de información de la Red de Investigación de Ecosistemas de China.

Traducido al español por Christine Harris.

Wang K, Wommack KE, Chen F. 2011. Abundance and distribution of Synechococcus spp. and cyanophages in the Chesapeake Bay. Appl. Environ. Microbiol. 77: 7459-7468. http://dx.doi.org/10.1128/AEM.00267-11

Wang YS, Lou ZP, Sun CC, Sun S. 2008. Ecological environment changes in Daya Bay, China, from 1982 to 2004. Mar. Pollut. Bull. 56: 1871-1879.

http://dx.doi.org/10.1016/j.marpolbul.2008.07.017

Wang ZH, Qi YZ, Chen JF, Xu N, Yang YF. 2006. Phytoplankton abundance, community structure and nutrients in cultural areas of Daya Bay, South China Sea. J. Mar. Syst. 62: 85-94. http://dx.doi.org/10.1016/j.jmarsys.2006.04.008

Wang ZH, Zhao JG, Zhang YJ, Cao Y. 2009. Phytoplankton community structure and environmental parameters in aquaculture areas of Daya Bay, South China Sea. J. Environ. Sci. (China) 21: 1268-1275.

http://dx.doi.org/10.1016/S1001-0742(08)62414-6

Wu ML, Wang YS. 2007. Using chemometrics to evaluate anthropogenic effects in Daya Bay, China. Estuar. Coast. Shelf Sci. 72: 732-742. http://dx.doi.org/10.1016/j.ecss.2006.11.032

Wu ML, Wang YS, Sun CC, Wang H, Dong JD, Han SH. 2009. Identification of anthropogenic effects and seasonality on water quality in Daya Bay, South China Sea. J. Environ. Manag. 90: 3082-3090.

http://dx.doi.org/10.1016/j.jenvman.2009.04.017

Wu ML, Wang YS, Sun CC, Wang H, Dong JD, Yin JP, Han SH. 2010. Identification of coastal water quality by statistical analysis methods in Daya Bay, South China Sea. Mar. Pollut. Bull. 60: 852-860.

http://dx.doi.org/10.1016/j.marpolbul.2010.01.007

Wu M-L, Wang Y-S, Sun C-C, Sun F-L, Cheng H, Wang Y-T, Dong J-D, Wu J. 2012. Monsoon-driven dynamics of water quality by multivariate statistical methods in Daya Bay, South China Sea. Oceanol. Hydrobiol. Stud. 41: 66-76. http://dx.doi.org/10.2478/s13545-012-0040-0

Xu GZ. 1989. Environments and resources of Daya Bay. Anhui Science Publishing House, HeFei, China.

Zhang X, Shi Z, Ye F, Zeng YY, Huang XP. 2013. Picophytoplankton abundance and distribution in three contrasting periods in the Pearl River Estuary, South China. Mar. Freshwat. Res. 64: 692-705.

http://dx.doi.org/10.1071/MF12303

Received July 2014, accepted August 2014. 